\title{
ANALISIS CALENDAR ANOMALIES DI PASAR SAHAM INDONESIA TAHUN 1998 - 2018
}

\author{
Hasna Fairuz Surachmadi \\ hasna16004@mail.unpad.ac.id \\ Anhar Fauzan Priyono \\ Heriyaldi \\ Departemen Ilmu Ekonomi, Fakultas Ekonomi dan Bisnis, Universitas Padjadjaran
}

\begin{abstract}
The Efficient Market Hypothesis Theory of Fama states that stock prices cannot be predicted by its movement tendency (random walk). In some stock markets, the movement of stock prices has a seasonal effect, which is the repetition of stock movements at a certain time that can be called a calendar anomalies. The repetition or seasonal effect on rate of return shows that the stock price can be predicted, thus it can be exploited by investors to get the probability of a higher rate of return. This research aims to see whether calendar anomalies prevail in the Indonesian stock market by using the daily and monthly rate of return of LQ45 and the Jakarta Composite Index (JCI) with an observation period of 21 years from 1998 to 2018 and estimated using the GARCH-M model $(1,1)$. The results of this research are the existence of daily anomalies on Monday as the day with the lowest rate of return and Wednesday as the day with the highest rate of return. In addition, we also get the results of monthly anomalies in August as the month with the lowest rate of return and December as the month with the highest rate of return.
\end{abstract}

Key words: day-of-the-week effect, January effect, GARCH-M, market anomalies

\begin{abstract}
ABSTRAK
Teori Efficient Market Hypothesis dari Fama menyebutkan bahwa harga saham tidak dapat diprediksi kecenderungan pergerakannya (random walk). Pada beberapa pasar saham di dunia, pergerakan dari harga saham memiliki seasonal effect, yaitu adanya pengulangan pergerakan saham pada suatu waktu tertentu yang dapat disebut sebagai calendar anomalies. Pengulangan atau seasonal effect pada tingkat pengembalian menunjukkan bahwa harga saham dapat diprediksi sehingga dapat diekploitasi oleh investor untuk mendapatkan probabilitas tingkat pengembalian yang lebih tinggi. Penelitian ini bertujuan untuk melihat apakah calendar anomalies berlaku di pasar saham Indonesia dengan menggunakan variabel tingkat pengembalian harian dan bulanan Indeks LQ45 dan Indeks Harga Saham Gabungan (IHSG) dengan periode observasi 21 tahun dari 1998 sampai 2018 serta diestimasi dengan menggunakan model GARCH-M (1,1). Hasil dari penelitian ini adalah adanya anomali harian pada hari Senin sebagai hari dengan tingkat pengembalian terendah dan hari Rabu sebagai hari dengan tingkat pengembalian tertinggi. Selain itu, didapat pula hasil adanya anomali bulanan pada bulan Agustus sebagai bulan dengan tingkat pengembalian terendah dan bulan Desember sebagai bulan dengan tingkat pengembalian tertinggi.
\end{abstract}

Kata kunci: day-of-the-week effect, January effect, GARCH-M, anomali pasar

\section{PENDAHULUAN}

Pergerakan harga saham selalu berubah dari waktu ke waktu. Dinyatakan dalam Efficient Market Hypothesis I, semakin efisien sebuah pasar saham maka perubahan harga yang terjadi akan semakin sulit diprediksi.
Hal tersebut dikarenakan pasar saham semakin cepat menggambarkan seluruh informasi yang ada atau dapat disebut juga harga yang muncul memenuhi asumsi random walk hypothesis (Malkiel dan Fama, 1970). Random walk hypothesis menjelaskan 
bahwa harga saham tidak dipengaruhi oleh harga saham pada periode sebelumnya dan dapat disebut juga sebagai keadaan pasar dengan tingkat efisiensi weak form test.

Harga yang menggambarkan seluruh informasi akan memperkecil peluang bagi investor untuk memiliki saham dengan harga yang overvalued maupun undervalued sehingga membuat para investor jarang mendapatkan tingkat pengembalian saham yang mengungguli pasar. Membeli saham yang berisiko lebih tinggi dengan harapan akan didapatkannya tingkat pengembalian yang lebih tinggi pula merupakan salah satu cara untuk bisa mendapatkan tingkat pengembalian saham yang lebih tinggi pada pasar saham. Tingkat pengembalian yang lebih tinggi pada saham dengan risiko yang lebih tinggi dianggap sebagai kompensasi dari risiko yang diterima oleh investor atau disebut juga sebagai risk-return tradeoff. Hubungan positif antara risiko dengan tingkat pengembalian dapat dijelaskan dengan Capital Asset Pricing Model (CAPM) yang persamaannya menunjukkan bahwa semakin tinggi koefisien dari beta, yang merupakan risiko suatu aset yang tidak terdiversifikasi, maka akan menghasilkan tingkat pengembalian yang lebih tinggi pula dengan asumsi hal-hal diluar model dianggap konstan (Gitman dan Zutter, 2015). Singkatnya, kata "efisien" pada Efficient Market Hypothesis I menyatakan bahwa investor tidak memiliki peluang untuk bisa memperoleh abnormal profits dari transaksi pasar modal (tidak dapat mengungguli pasar).

Pada kenyataannya, terdapat perbedaan dari teori Efficient Market Hypothesis I dengan apa yang sebenarnya terjadi, yaitu bahwa tidak semua pasar saham dapat sepenuhnya efisien jika mengikuti kriteria pada hipotesis tersebut. Penelitian dari Guidi et al. (2011) memperkuat pernyataan tersebut dengan hasil penelitian bahwa indeks pasar saham di Central and Eastern Europe (CEE) dengan menggunakan analisis autokorelasi tidak memenuhi asumsi random walk hypothesis, khususnya saat CEE tergabung dalam European Union, begitu pula penelitian dari Borges (2010) untuk di negara Prancis dan Inggris. Bukti lainnya bahwa efisiensi pasar saham tidak dapat sepenuhnya dijelaskan dalam Efficient Market Hypothesis I adalah harga saham yang dapat dilihat kecenderungan pergerakannya pada suatu waktu tertentu atau adanya seasonal effect. Hal tersebut mendasari adanya pengembangan dari Efficient Market Hypothesis I, yaitu Efficient Market Hypothesis II, yang mempertimbangkan adanya efek seasonal pada tingkat pengembalian (Fama, 1991). Adanya efek seasonal pada tingkat pengembalian dapat disebut juga sebagai anomali karena fenomena tersebut tidak hilang walaupun informasinya sudah diketahui oleh investor.

Efek seasonal pada tingkat pengembalian atau calendar anomalies pertama kali terdokumentasi pada Indeks Dow-Jones oleh Fields (1931) dan Wachtel (1942). Kedua penelitian tersebut menjelaskan bahwa tingkat pengembalian Indeks DowJones pada hari Sabtu cenderung lebih tinggi dibandingkan hari Jumat dan hari Senin Fields (1931) serta tingkat pengembalian bulan Januari yang cenderung lebih tinggi dibandingkan bulan Desember (Wachtel, 1942). Kedua penelitian itu mendorong banyaknya penelitian-penelitian lain dengan harapan dapat menjelaskan anomali pasar tersebut sehingga day-of-theweek effect dan January effect merupakan bentuk calendar anomalies yang banyak menjadi perhatian di kalangan akademisi.

Adanya day-of-the-week effect didukung oleh beberapa penelitian yang melihat pasar saham di Amerika Serikat. Penelitian dari Berument dan Dogan (2012) yang menggunakan data indeks NYSE, S\&P500, NASDAQ, AMEX, dan DOW mendapat hasil bahwa dengan expected returns dari hari Senin selalu negatif dan terendah dibandingkan hari lain dalam seminggu. Selain itu, didapatkan pula hasil bahwa tingkat pengembalian pada hari Jumat lebih tinggi dibandingkan hari Senin dan tingkat pengembalian tertinggi jatuh pada hari 
Rabu atau Jumat. Penelitian lain oleh Urquhart dan McGroarty (2014) mendapat hasil bahwa tingkat pengembalian pada hari Senin adalah negatif pada empat dari enam subsampel, yaitu pada tahun 19191937, 1938-1956, serta 1957-1975 dan pada keseluruhan data yaitu dari tahun 1900-2013 yang diteliti dengan menggunakan Indeks Dow Jones Industrial Averages. Selain pada pasar saham Amerika Serikat, day-of-theweek effect juga muncul pada pasar saham negara lainnya yang dibuktikan dengan penelitian dari Ariss et al.(2011) yang mendapat hasil bahwa tingkat pengembalian pada hari Rabu di negara-negara Gulf Cooperation Council (Abu Dhabi, Bahrain, Kuwait, Muscat, Qatar, Saudi Arabia, dan Dubai) adalah positif secara signifikan.

Berbeda dengan day-of-the-week effect, January effect merupakan anomali yang menunjukkan adanya kebiasaan tingkat pengembalian positif yang jatuh pada bulan Januari. Pernyataan tersebut didukung oleh penelitian dari Perez (2018) yang membuktikan dengan pengujian Wilcoxon bahwa adanya tingkat pengembalian yang lebih tinggi di bulan Januari dibandingkan bulan lainnya pada pasar saham di beberapa negara seperti Amerika Serikat, Israel, Lebanon, Filipina, dan Sri Lanka. Ada pula penelitian lainnya dari Agnani dan Aray (2011) membuktikan dengan menggunakan sampel data value-weighted returns bulanan pada lima jenis portfolio di Amerika Serikat pada tahun 1940-2006 bahwa adanya tingkat pengembalian yang lebih tinggi dibandingkan bulan lainnya pada bulan Januari untuk kelima jenis portfolio tersebut.

Indonesia merupakan salah satu negara yang tidak luput dari adanya day-of-the-week effect. Zhang et al. (2017) mendapatkan hasil pada penelitiannya yang menggunakan sampel Indeks Harga Saham Gabungan (IHSG) tahun 1990-2016. Hasil tersebut menjelaskan bahwa terdapat day-of-the-week effect pada IHSG pada hari Rabu yang di mana tingkat pengembalian indeks itu positif dan paling tinggi dibandingkan hari lainnya

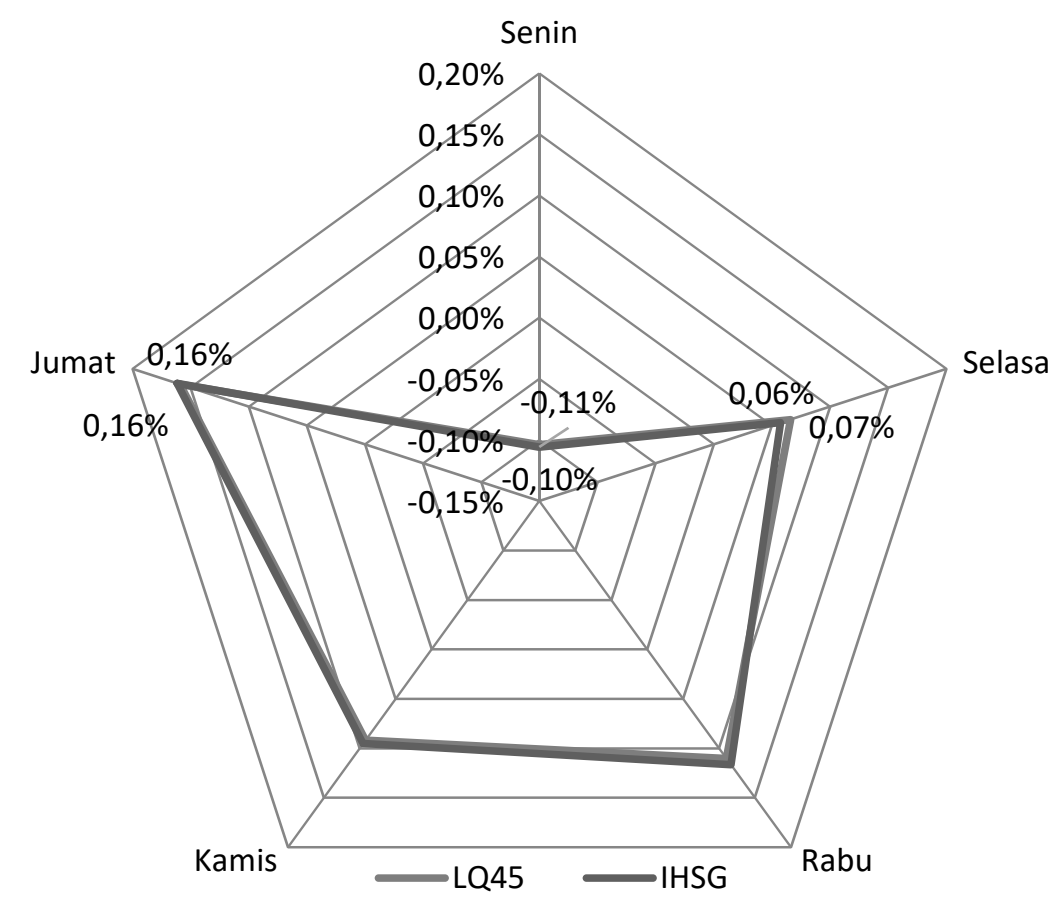

Gambar 1

Rata-Rata Return Harian Indeks LQ45 dan IHSG Tahun 1998-2018

Sumber: webpage Investing dan Yahoo Finance, diolah (2020) 
Gambar 1 menunjukkan bahwa pergerakan tingkat pengembalian harian pada Indeks LQ45 dan IHSG memiliki konsistensi yang sama di mana tingkat pengembalian terendah jatuh pada hari Senin dan tingkat pengembalian tertinggi jatuh pada hari Jumat. Selain itu, tingkat pengembalian pada hari Selasa, Rabu, dan Kamis menunjukkan kestabilan yang di mana nilai tingkat pengembalian ketiga hari tersebut tidak jauh berbeda.

January effect juga muncul pada pasar saham Indonesia yang dibuktikan oleh penelitian dari Fitriyani (2013) yang mendapat hasil bahwa terbuktikan adanya January effect di Bursa Efek Indonesia secara signifikan dengan melihat tingkat pengembalian Indeks LQ45 untuk tahun 2009-2011. Walaupun begitu, ada pula penelitian lain dari Simbolon (2015) yang menunjukkan bahwa tidak adanya January effect pada 12 emiten yang terdaftar pada Indeks LQ4 dengan menggunakan periode data tahun 20062013.

Gambar 2 menunjukkan sifat pergerakan Indeks LQ45 dan IHSG yang searah di mana tingkat pengembalian terendah jatuh pada bulan Agustus sedangkan tingkat pengembalian tertinggi jatuh pada bulan Desember. Selain kedua bulan tersebut, tingkat pengembalian yang dihasilkan kedua indeks bergerak secara konsisten dengan nilai yang berbeda-beda. Kekonsistenan tersebut dapat dilihat dengan kesamaan nilai tingkat pengembalian positif maupun negatif pada kedua indeks. Grafik 2 juga menunjukkan tidak adanya January effect karena tingkat pengembalian bulan Januari bukanlah tingkat pengembalian tertinggi walaupun bernilai positif.

Walaupun menunjukkan adanya inefisiensi pasar, adanya calendar anomalies di pasar saham dapat menguntungkan bagi investor karena memberi kesempatan untuk mengeksploitasi calendar anomalies dengan tujuan mendapat tingkat pengembalian yang lebih tinggi. Eksploitasi tersebut dapat dalam bentuk pembelian saham pada hari dengan kebiasaan tingkat pengembalian cenderung rendah dan menjualnya kembali pada hari dengan kebiasaan tingkat pengembalian cenderung tinggi. Karena itu, dengan mengetahui bagaimana day-of-theweek effect dan January effect berlaku di pasar saham dapat memengaruhi keputusan yang diambil oleh investor.

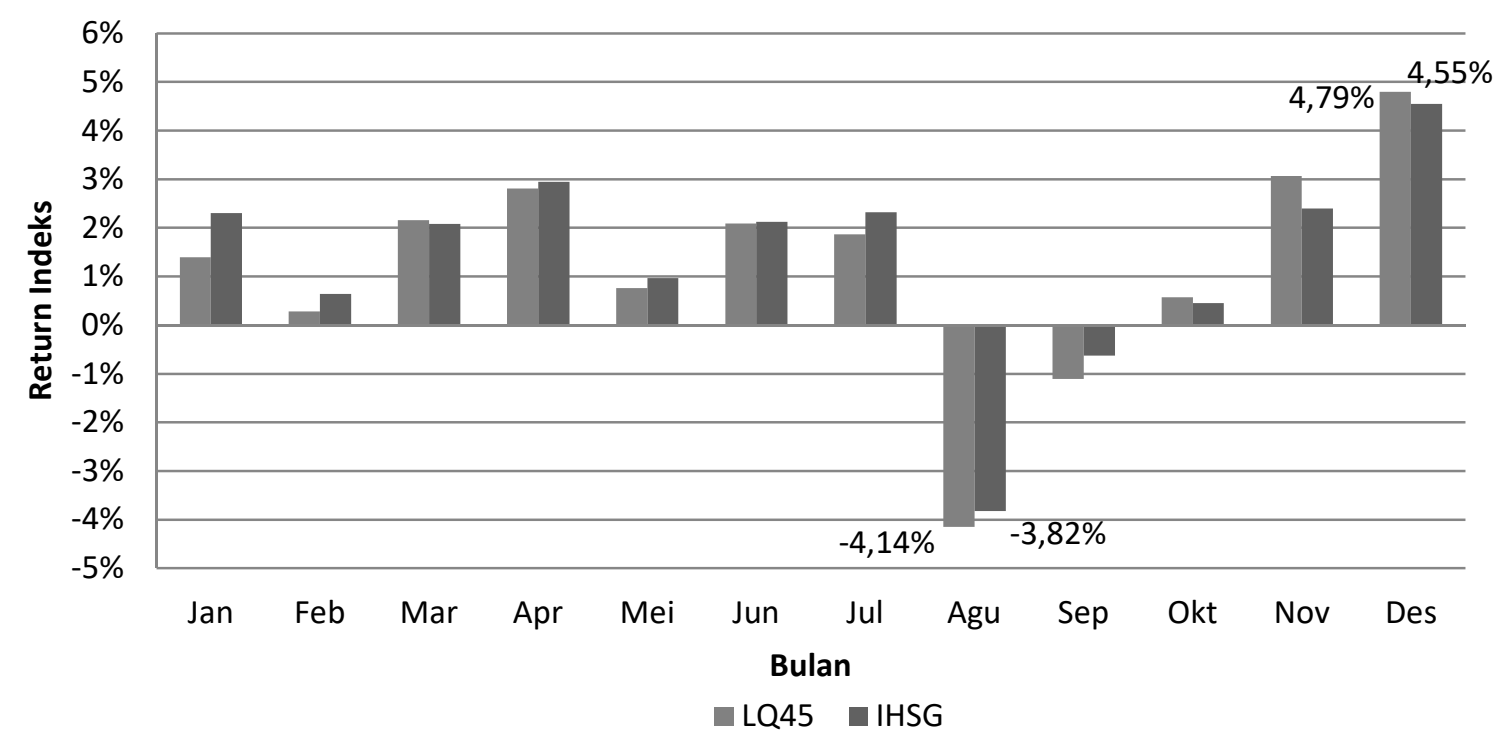

Gambar 2

Rata-Rata Return Bulanan Indeks LQ45 dan IHSG Tahun 1998-2018

Sumber: webpage Investing dan Yahoo Finance, diolah (2020) 
Berdasarkan paparan sebelumnya, maka tujuan yang ingin dicapai pada penelitian ini adalah: (1) bagaimana day-of-the-week effect berlaku pada tingkat pengembalian Indeks LQ45 dan IHSG?; dan (2) bagaimana January effect berlaku pada tingkat pengembalian Indeks LQ45 dan IHSG.

\section{TINJAUAN TEORETIS Pasar Modal}

Pasar modal merupakan jenis pasar yang masuk ke dalam pasar keuangan. Salah satu fungsi utama dari pasar keuangan adalah mempertemukan pihak yang membutuhkan dana dengan pihak yang memiliki dana. Walaupun begitu, pasar keuangan berbeda dengan perantara keuangan. Perbedaan dari kedua hal tersebut adalah bagaimana dana berpindah dari pihak yang memiliki dana (lenders) ke pihak yang membutuhkan dana (borrowers). Dengan perantara keuangan, dana yang berpindah dari lenders kepada borrowers harus melalui perantara seperti bank, reksa dana, bank investasi atau dana pensiun, sehingga disebut juga sebagai pendanaan tidak langsung. Berbeda dengan perantara keuangan, pasar keuangan tidak menggunakan perantara sehingga dana dari lenders dapat langsung berpindah kepada borrowers sehingga disebut juga sebagai pendanaan langsung.

Pasar modal memiliki produk yang diperjualbelikan sebagai pemindah dana dari lenders kepada borrowers. Produk tersebut adalah obligasi atau surat utang, yang dimana adanya pembayaran secara periodik pada suatu waktu tertentu dan saham yang merupakan bukti kepemilikan seseorang di suatu perusahaan (Mishkin, 2016). Seseorang dapat memiliki bukti kepemilikan di sebuah perusahaan dengan membeli saham jika perusahaan tersebut sudah melakukan penawaran umum. Menurut Undang-Undang Republik Indonesia Nomor 8 Tahun 1995 Tentang Pasar Modal, penawaran umum adalah kegiatan penawaran efek yang dilakukan oleh emiten untuk menjual efek kepada masyarakat berdasarkan tata cara yang diatur dalam undang-undang ini dan peraturan pelaksanaannya. Perusahaan dapat disebut sudah melakukan penawaran umum jika perusahaan tersebut sudah terdaftar pada bursa efek. Saat perusahaan sudah melakukan penawaran umum (Initial Public Offering/Go Public), banyak manfaat yang bisa didapat untuk perusahaan tersebut seperti adanya akses bagi perusahaan untuk sarana pendanaan jangka panjang, meningkatkan nilai dan image perusahaan dan adanya insentif pajak.

\section{Saham}

Menurut Bursa Efek Indonesia, saham merupakan tanda penyertaan modal seseorang atau pihak (badan usaha) dalam suatu perusahaan atau perseroan terbatas. Penyertaan modal tersebut merupakan salah satu bentuk tanda kepemilikan seseorang atas suatu badan usaha tertentu. Semakin banyak saham yang dimiliki seseorang menunjukkan kepemilikan seseorang yang semakin besar. Dengan memiliki saham, seseorang dapat memiliki beberapa bentuk keuntungan. Keuntungan tersebut bisa dalam bentuk pembagian keuntungan perusahaan (dividen) atau dalam bentuk selisih antara harga beli dengan harga jual saham (capital gain). Dalam pasar modal, ada dua jenis saham yang diperjualbelikan, yaitu saham biasa (common stock) dan saham preferen (preferred stock).

Saham biasa merupakan saham yang diperjualbelikan secara terbuka di bursa efek sedangkan saham preferen merupakan saham dengan bentuk yang berbeda dibandingkan saham biasa karena memiliki karakteristik gabungan antara obligasi dan saham biasa. Hal tersebut ditunjukkan dengan para pemegang saham yang dijanjikan adanya pembayaran dividen secara berkala yang harus dibayarkan sebelum adanya pembagian dividen untuk pemegang saham biasa (Gitman dan Zutter, 2015). 


\section{Indeks Harga Saham}

Dalam memudahkan investor untuk menilai sebuah investasi, salah satu alat yang dapat digunakan adalah dengan melihat indeks harga saham. Indeks harga saham adalah suatu pengukuran dari sekumpulan saham tertentu pada pasar saham. Indeks ini merupakan salah satu alat yang dapat digunakan investor untuk menggambarkan pasar dan untuk membandingkan tingkat pengembalian suatu investasi tertentu. Menurut Lo (2016), indeks harga saham memiliki dua fungsi, yaitu sebagai sumber informasi karena memberikan pengukuran secara umum tentang performa investasi dan sebagai basis untuk perbandingan performa saham. Indonesia merupakan salah satu negara yang memiliki banyak jenis indeks harga saham, seperti IHSG (IHSG), LQ45, JII (Jakarta Islamic Index), Sri-Kehati, dan lainlain. Banyaknya indeks saham di Indonesia bertujuan untuk memudahkan para investor untuk melihat pertumbuhan atau pelambatan perubahan nilai harga saham secara agregat atau keseluruhan sesuai dengan indeks yang digunakan karena setiap indeks memiliki karakteristik anggotanya masing-masing. Indeks yang digunakan pada penelitian ini adalah Indeks LQ45 dan IHSG. Indeks LQ45 atau LiQuid 45 merupakan indeks yang beranggotakan 45 saham paling likuid di Bursa Efek Indonesia. Pemilihan perusahaan yang masuk ke dalam LQ45 dilakukan dengan adanya seleksi atas penilaian likuiditas dan kapitalisasi pasarnya yang setiap enam bulan sekali (Februari dan Agustus) adanya pembaharuan anggota sesuai dengan performa perusahaan. Faktor lain yang harus dipenuhi dan menjadi pertimbangan untuk dapat masuk ke dalam perhitungan Indeks LQ45 adalah perusahaan telah tercatat di BEI minimal 3 bulan, aktivitas transaksi perusahaan di pasar reguler (nilai, volume, dan frekuensi transaksi), jumlah hari perdagangan di pasar reguler, kapitalisasi pasar pada periode waktu tertentu, dan melihat pula keadan keuangan dan prospek pertumbuhan perusahaan. Berbeda dengan LQ45, IHSG merupakan indeks yang mengukur pergerakan semua saham yang tercatat di Bursa Efek Indonesia sehingga dianggap dapat menggambarkan keadaan pasar saham secara keseluruhan di Indonesia.

\section{Risiko}

Risiko menurut Gitman dan Zutter (2015) merupakan sebuah pengukuran untuk ketidakpastian dari tingkat pengembalian yang akan didapat dari sebuah investasi. Semakin tidak pastinya sebuah tingkat pengembalian maka dapat dikatakan bahwa investasi tersebut semakin berisiko. Walaupun begitu, tingkat pengembalian yang diharapkan dari investasi dengan risiko tinggi akan tinggi pula akibat dari tingkat pengembalian yang dianggap sebagai kompensasi dari tingginya risiko yang ada. Hal tersebut sesuai dengan istilah "high risk, high return". Gitman dan Zutter (2015) membagi risiko di pasar saham menjadi beberapa jenis, yaitu:

\section{Diversifiable risk}

Risiko ini merupakan salah satu jenis risiko yang muncul akibat dari hal-hal tidak terduga yang terjadi di suatu perusahaan, seperti penyerangan perusahaan, gugatan hukum, dan lain-lain. Dampak dari peristiwa-peristiwa tersebut dapat diminimalisir dengan adanya diversifikasi atau kepemilikan jenis saham yang berbedabeda.

\section{Nondiversifiable risk}

Berbeda dengan diversifiable risk, risiko jenis ini tidak dapat diminimalisir dengan adanya diversifikasi jenis saham karena risiko ini muncul akibat dari kondisi pasar yang memengaruhi semua perusahaan. Risiko ini dapat disebut juga sebagai risiko sistematis. Faktor yang dapat memunculkan risiko ini adalah adanya perang, inflasi, peristiwa politik, dan lain-lain. 


\section{Tingkat Pengembalian Saham}

Tingkat pengembalian menurut Gitman dan Zutter (2015) merupakan pengukuran yang menunjukkan jumlah untung atau rugi yang dihasilkan dari sebuah investasi pada waktu tertentu. Untung atau rugi yang dihasilkan dapat diukur untuk intra periode maupun antar periode. Intra periode merupakan perhitungan yang menunjukkan tingkat pengembalian dalam satu periode dari mulai pasar dibuka hingga pasar ditutup. Metode tersebut menggunakan harga pembuka dan penutup suatu saham. Berbeda dengan intra periode, antar periode menunjukkan tingkat pengembalian untuk periode yang berbeda. Metode ini menggunakan harga pembuka atau penutup pada periode yang berbeda. Penelitian ini menggunakan tingkat pengembalian antar periode yang persamaannya adalah sebagai berikut:

Di mana:

$$
R_{t}=\frac{P_{t}-P_{t-1}}{P_{t-1}} \times 100 \%
$$

$$
\begin{aligned}
R_{t}= & \text { Tingkat pengembalian periode } \mathrm{t} \\
P_{t}= & \text { Harga penutup saham pada } \\
& \text { periode } \mathrm{t} \\
P_{t-1}= & \begin{array}{l}
\text { Harga penutup saham pada } \\
\text { periode sebelumnya }(\mathrm{t}-1)
\end{array}
\end{aligned}
$$

\section{Efficient Market Hypothesis}

Merujuk pada penelitian Malkiel dan Fama (1970), dalam pelaksanaannya, salah satu peran utama dari pasar modal adalah adanya pengalokasian modal. Pasar yang dianggap paling baik adalah pasar yang harganya merupakan tanda akurat yang memengaruhi keputusan investor dalam alokasi saham tersebut. Karena itu, harga yang ada harus memenuhi asumsi bahwa harga sepenuhnya menggambarkan seluruh informasi yang ada, dalam hal ini dapat disebut juga dengan efisien. Semakin efisiennya suatu pasar maka akan mengakibatkan harga saham yang semakin tidak dapat diprediksi akibat dari sifat informasi yang secara acak untuk muncul di pasar dan semakin cepatnya harga bereaksi terhadap informasi yang ada.
Ada beberapa tingkatan yang dikemukakan oleh Malkiel dan Fama (1970) tentang seberapa efisien sebuah pasar, yaitu:

Weak form test

Salah satu tingkatan yang menunjukkan bahwa harga saham sudah mencerminkan informasi yang ada dengan mempertimbangkan data historisnya. Pada tingkatan ini, pasar saham sudah disebut efisien jika data historis tidak memengaruhi harga saham untuk periode selanjutnya, yang artinya bahwa performa sebelumnya tidak memengaruhi performa masa depan. Hal tersebut menunjukkan bahwa analisis yang hanya mengandalkan data historis serta tren harga saham akan sia-sia. Tingkatan ini juga menyebutkan bahwa harga bergerak secara acak (random walk theory).

\section{Semi-strong form test}

Berbeda dengan weak form test, tingkatan ini menunjukkan bahwa harga saham yang ada sudah memuat seluruh informasi publik yang muncul. Tingkatan ini melihat bagaimana harga yang ada secara efisien mampu untuk menyesuaikan dengan informasi publik lain yang ada.

\section{Strong form test}

Strong form test merupakan tingkatan efisiensi yang paling tinggi pada teori Efficient Market Hypothesis. Tingkatan ini menunjukkan bahwa semua informasi yang bersifat publik maupun pribadi dipertimbangkan dalam harga saham yang ada di pasar. Pada tingkat ini pula dapat dilihat apakah adanya beberapa investor atau suatu kelompok yang memiliki akses untuk segala informasi berkaitan dengan pembentukan harga secara monopolistik.

Karena kurangnya kemampuan Efficient Market Hypothesis pada masa itu untuk menjelaskan beberapa hal, maka ada perkembangan dari teori tersebut oleh Fama (1991) menjadi Efficient Market Hypothesis II. Teori tersebut menjelaskan bahwa harga saham sepenuhnya menggambarkan informasi yang ada. Pengembangan ini didasari adanya permasalahan hipotesis karena 
penelitian tersebut hanya menjelaskan bahwa kita dapat menguji apakah harga secara penuh menggambarkan informasi yang ada dalam konteks pricing model. Pengembangan ini lalu mengubah tingkatan efisiensi pasar menjadi:

Test for return predictability

Permasalahan efisiensi pasar dan equilibrium-pricing tidak dapat dipisahkan sehingga tingkatan ini mempertimbangkan adanya pengujian asset-pricing models dan anomali pasar. Bukti bahwa adanya tingkat pengembalian seasonal dan harga yang sangat bervolatilitas juga menjadi pertimbangan dalam lingkup return predictability.

\section{Event studies}

Salah satu tingkatan yang paling dekat untuk dapat menyelesaikan adanya permasalahan efisiensi pasar dan equilibrium-pricing karena memberikan bukti tingkat efisiensi secara langsung.

\section{Tests for private information}

Tingkatan yang meluruskan bukti bahwa para pekerja perusahaan memiliki informasi yang tidak tergambarkan pada harga saham. Walaupun begitu, apakah para pekerja perusahaan memiliki informasi tersendiri atau tidak masih diikuti dengan permasalahan hipotesis.

\section{Day-of-the-week effect}

Day-of-the-week effect atau biasa dikenal juga dengan weekend effect merupakan salah satu anomali yang terjadi di pasar saham. Anomali ini menunjukkan adanya kebiasaan sifat tingkat pengembalian pada suatu hari tertentu. Dalam hal ini, day-of-the-week effect menunjukkan bahwa adanya tingkat pengembalian yang relatif tinggi di hari Jumat dan tingkat pengembalian hari Senin yang sangat rendah. Ada beberapa argumen yang disimpulkan oleh Berument dan Dogan (2012) bahwa perusahaan cenderung akan mengumumkan berita buruk pada saat pasar saham menuju tutup, yaitu pada hari Jumat untuk menunda penurunan harga saham. Hal tersebut mendorong harga saham pada hari Senin cenderung rendah. Selain itu, adanya penurunan volume transaksi pada hari Senin karena dianggap merupakan hari yang strategis untuk merencanakan investasi untuk seminggu ke depan.

Fenomena ini menjadi salah satu perhatian para akademisi, ditunjukkan dengan berbagai penelitian yang mencoba untuk menjelaskan fenomena tersebut. Penelitian dari Urquhart dan McGroarty (2014), yang merupakan rujukan utama penelitian ini, memperkuat bukti bahwa adanya day-of-the-week effect di mana tingkat pengembalian pada hari Senin cenderung lebih rendah dibandingkan hari lainnya pada Indeks Dow Jones Industrial dengan mengestimasi menggunakan model volatiletas GARCH $(1,1)$. Selain penelitian tersebut, ada pula penelitian dari Ariss et al., (2011), Berument dan Dogan (2012), serta Zhang et al. (2017) yang mendapat hasil serupa, yaitu adanya day-of-the-week effect di berbagai pasar saham dunia.

\section{January effect}

Salah satu bentuk dari anomali pasar adalah January effect, di mana adanya perbedaan signifikan tingkat pengembalian pada suatu bulan tertentu, yang pada kasus ini jatuh pada bulan Januari. Fenomena ini menangkap bahwa pada bulan Januari, tingkat pengembalian suatu perusahaan cenderung lebih tinggi dibandingkan dengan bulan lainnya pada tahun yang sama. Menurut Agnani dan Aray (2011), diantar berbagai penjelasan mengenai fenomena ini, salah satu hipotesis yang paling terkenal adalah adanya penjualan saham untuk menghindari pajak. Sesaat sebelum pergantian tahun, investor akan menjual sekuritas mereka untuk menghindari adanya pengenaan pajak dari net capital gains sehingga adanya tekanan jual di akhir tahun. Setelah pergantian tahun, harga akan melambung sehingga menyebabkan tingkat pengembalian yang tinggi di bulan Januari. Selain itu, January effect juga seringkali berhubungan dengan saham dari perusahaan kecil yang 
cenderung untuk melakukan penjualan penghindaran pajak tersebut.

Beberapa penelitian yang membahas dan membuktikan bahwa January effect berlaku di beberapa pasar saham antara lain adalah penelitian dari Perez (2018) dan Urquhart dan McGroarty (2014) sedangkan penelitian yang menunjukkan bahwa January effect tidak berlaku, melainkan adanya anomali pada bulan lain adalah penelitian dari Ariss et al. (2011).

\section{METODE PENELITIAN}

\section{Data}

Penelitian ini menggunakan data runut waktu (time series) yang merupakan data sekunder bersumber dari webpage Yahoo Finance dan Investing, dapat dilihat pada Tabel 1 sampai dengan Tabel 4. Data diambil dalam bentuk data harga penutup harian dan bulanan dari Indeks LQ45 serta IHSG dengan periode selama 21 tahun dari 1 Januari 1998 sampai 31 Desember 2018. Data yang digunakan konsisten untuk kedua indeks dengan jumlah observasi sebanyak 5,114, rata-rata tingkat pengem-balian terendah jatuh pada hari Senin, dan rata-rata tingkat pengembalian tertinggi jatuh pada hari Rabu.

Pada data bulanan pula dapat dilihat bahwa data untuk LQ45 dan IHSG memiliki pergerakan yang sama di mana rata-rata tingkat pengembalian terendah ada pada bulan Agustus sedangkan rata-rata tingkat pengembalian tertinggi ada pada bulan Desember dengan jumlah observasi sebanyak 251.

Tabel 1

Ringkasan Statistik Return Harian LQ45

\begin{tabular}{lccccc}
\hline \hline Variabel & $\mathbf{N}$ & Mean & SD & Min & Max \\
\hline Senin & 1,017 & -0.1238 & 2.003 & -13.81 & 15.44 \\
Selasa & 1,035 & 0.0505 & 1.753 & -12.87 & 12.44 \\
Rabu & 1,054 & 0.0939 & 1.803 & -12.63 & 9.106 \\
Kamis & 1,013 & 0.0738 & 1.896 & -15.80 & 11.35 \\
Jumat & 995 & 0.1439 & 1.728 & -8.556 & 14.04 \\
Return (all) & 5,114 & 0.0476 & 1.840 & -15.79 & 15.20 \\
\hline
\end{tabular}

Sumber: webpage Investing (2020)

Tabel 2

Ringkasan Statistik Return Harian IHSG

\begin{tabular}{lrrrrr}
\hline \hline Variabel & N & Mean & SD & Min & Max \\
\hline Senin & 1,017 & -0.1202 & 1.687 & -10.93 & 13.13 \\
Selasa & 1,035 & 0.0495 & 1.459 & -9.293 & 11.49 \\
Rabu & 1,054 & 0.1032 & 1.508 & -10.95 & 7.623 \\
Kamis & 1,013 & 0.0848 & 1.550 & -12.73 & 8.073 \\
Jumat & 995 & 0.1486 & 1.411 & -7.155 & 10.20 \\
Return (all) & 5,114 & 0.0531 & 1.528 & -12.73 & 13.13 \\
\hline
\end{tabular}

Sumber: webpage Investing (2020)

Tabel 3

Ringkasan Statistik Return Bulanan LQ45

\begin{tabular}{lrrrrr}
\hline Variabel & N & Mean & SD & Min & Max \\
\hline Januari & 20 & 1.148 & 7.027 & -10.64 & 19.14 \\
Februari & 21 & 0.177 & 4.667 & -12.47 & 8.009 \\
Maret & 21 & 1.891 & 7.160 & -14.29 & 14.07 \\
April & 21 & 2.222 & 10.70 & -20.36 & 25.50
\end{tabular}


212 Ekuitas: Jurnal Ekonomi dan Keuangan - Volume 5, Nomor 2, Juni 2021 : 203 - 223

\begin{tabular}{lrrrrr}
\hline Variabel & N & Mean & SD & Min & \multicolumn{1}{l}{ Max } \\
\hline Mei & 21 & 0.438 & 8.252 & -17.37 & 15.75 \\
Juni & 21 & 1.925 & 5.440 & -7.460 & 14.07 \\
Juli & 21 & 1.668 & 6.186 & -11.38 & 14.75 \\
Agustus & 21 & -4.622 & 9.418 & -40.52 & 6.015 \\
September & 21 & -1.632 & 10.62 & -29.84 & 15.24 \\
Oktober & 21 & -0.027 & 11.73 & -42.49 & 14.32 \\
November & 21 & 2.607 & 9.050 & -7.833 & 33.54 \\
Desember & 21 & 4.576 & 4.699 & -5.816 & 15.72 \\
Return (all) & 251 & 0.863 & 8.370 & -42.49 & 33.54 \\
\hline
\end{tabular}

Sumber: webpage Yahoo Finance (2020)

Tabel 4

Ringkasan Statistik Return Bulanan IHSG

\begin{tabular}{lccccc}
\hline Variabel & N & Mean & SD & Min & Max \\
\hline Januari & 20 & 1.211 & 5.550 & -8.981 & 14.15 \\
Februari & 21 & 0.575 & 3.585 & -9.874 & 7.400 \\
Maret & 21 & 1.885 & 6.125 & -11.69 & 11.55 \\
April & 21 & 2.465 & 9.571 & -16.27 & 22.96 \\
Mei & 21 & 0.661 & 7.965 & -14.79 & 16.70 \\
Juni & 21 & 1.969 & 5.183 & -6.040 & 12.56 \\
Juli & 21 & 2.126 & 5.860 & -10.19 & 13.65 \\
Agustus & 21 & -4.203 & 8.307 & -34.13 & 5.723 \\
September & 21 & -1.023 & 9.130 & -21.51 & 12.76 \\
Oktober & 21 & $7.9 \mathrm{e}-4$ & 10.16 & -37.72 & 11.38 \\
November & 21 & 2.142 & 6.855 & -5.800 & 25.02 \\
Desember & 21 & 4.369 & 3.981 & -3.050 & 14.80 \\
Return (all) & 251 & 1.014 & 7.306 & -37.72 & 25.02 \\
Sumber: webpage Yahoo Finance $\mathbf{( 2 0 2 0}$ & & &
\end{tabular}

\section{METODE PENELITIAN}

Penelitian ini mengunakan dua metode analisis, yaitu metode deskriptif dan kuantitatif. Metode deskriptif digunakan untuk menjelaskan hasil yang didapat dengan melihat kondisi dan hubungan yang terjadi. Metode kuantitatif merupakan metode pengolahan dengan menggunakan data numerik agar menghasilkan hasil dan pengukuran yang objektif. Model yang digunakan dalam pengolahan data adalah model volatilitas GARCH-M $(1,1)$. Pengolahan data akan dilakukan dengan menggunakan program STATA 14.

Variabel yang digunakan merupakan variabel tingkat pengembalian harian dan bulanan dari Indeks LQ45 dan IHSG pada periode 1 Januari 1998 sampai 31 Desember 2018. Melihat penelitian dari Urquhart dan
McGroarty (2014), maka perhitungan tingkat pengembalian menggunakan rumus sebagai berikut:

$R_{t}=\left[\ln \left(P_{t}\right)-\ln \left(P_{t}-1\right)\right] \times 100$

Di mana:

$R_{t}=$ Tingkat pengembalian periode $\mathrm{t}$

$P_{t}=$ Harga penutup indeks pada periode $t$

$P_{t-1}=$ Harga penutup indeks pada periode sebelumnya $(t-1)$

Tingkat pengembalian dengan rumus (3.1) menunjukkan bahwa tingkat pengembalian yang digunakan merupakan tingkat pengembalian yang membandingkan harga penutup pada periode $t$ dengan harga penutup pada periode sebelumnya ( $t-$ 1) sehingga hasil tingkat pengembalian 
menunjukkan tingkat pengembalian antar periode, bukan intra periode.

Merujuk pada penelitian Zhang et al. (2017), model yang digunakan pada penelitian ini adalah model dengan dasar GARCH $(1,1)$. Model GARCH dikembangkan oleh Bollerslev (1986) yang memungkinkan model untuk menangkap varians antar waktu karena persamaan conditional variance menempatkan varians sebagai dependen sehingga model ini tepat untuk digunakan pada penelitian ini. GARCH merupakan model dasar yang dipilih dalam penelitiannya didasari oleh kelebihan yang dimiliki dibandingkan dengan model $\mathrm{ARCH}$.

Persamaan yang digunakan merujuk pada penelitian Zhang et al. (2017) adalah sebagai berikut untuk day-of-the-week effect:

$$
R t=a_{0}+a_{1} T_{t}+a_{2} W_{t}+a_{3} H_{t}+a_{4} F_{t}+a_{5} R_{t-1}+\varepsilon_{t}
$$

$h_{\mathrm{t}}^{2}=\beta_{0}+\beta_{1} \varepsilon_{\mathrm{t}-1}^{2}+\beta_{2} \mathrm{~h}_{\mathrm{t}-1}^{2}$

Didapat pula dua persamaan untuk melihat January effect sebagai berikut:

$R \mathrm{t}=\mathrm{a}_{0}+\mathrm{a}_{1} \mathrm{FEB}_{\mathrm{t}}+\ldots .+\mathrm{a}_{11} \mathrm{DES}_{\mathrm{t}}+\mathrm{a}_{12} \mathrm{R}_{\mathrm{t}-1}+\varepsilon_{\mathrm{t}}$

$\mathrm{h}_{\mathrm{t}}^{2}=\beta_{0}+\beta_{1} \varepsilon_{\mathrm{t}-1}^{2}+\beta_{2} \mathrm{~h}_{\mathrm{t}-1}^{2}$

Untuk mencapai tujuan penelitian, peneliti memasukkan volatilitas ke dalam persamaan conditional mean sehingga model yang digunakan berubah menjadi GARCHM $(1,1)$. Hal itu dilakukan untuk melihat bagaimana risiko dapat berpengaruh terhadap tingkat pengembalian. Dengan menggunakan model GARCH-M (1,1), maka didapatlah dua persamaan untuk melihat day-of-the-week effect sebagai berikut:

$R t=a_{0}+a_{1} T_{t}+a_{2} W_{t}+a_{3} H_{t}+a_{4} F_{t}+a_{5} R_{t-1}+\gamma h_{t}+\varepsilon_{t}$

$\mathrm{h}_{\mathrm{t}}^{2}=\beta_{0}+\beta_{1} \varepsilon_{\mathrm{t}-1}^{2}+\beta_{2} \mathrm{~h}_{\mathrm{t}-1}^{2}$
Didapat pula dua persamaan untuk melihat January effect sebagai berikut:

$$
\begin{aligned}
& \mathrm{Rt}=\mathrm{a}_{0}+\mathrm{a}_{1} \mathrm{FEB}_{\mathrm{t}}+\ldots .+\mathrm{a}_{11} \operatorname{DES}_{\mathrm{t}}+\mathrm{a}_{12} \mathrm{R}_{\mathrm{t}-1}+\gamma \mathrm{h}_{\mathrm{t}}+ \\
& \varepsilon_{\mathrm{t}} \\
& \mathrm{h}_{\mathrm{t}}^{2}=\beta_{0}+\beta_{1} \varepsilon_{\mathrm{t}-1}^{2}+\beta_{2} \mathrm{~h}_{\mathrm{t}-1}^{2}
\end{aligned}
$$

dengan variabel $R_{t}$ (tingkat pengembalian periode $\mathrm{t}$ ), $T_{t}, W_{t}, H_{t}, F_{t}$ (Dummy hari SelasaJumat), $F E B_{t}, \ldots D E S_{t}$ (Dummy bulan FebDes), $R_{t-1}$ (tingkat pengembalian periode sebelumnya $\mathrm{t}-1), \quad \gamma h_{t}$ (varians tingkat pengembalian), $\varepsilon_{t}$ (error term), $\alpha_{1}-\alpha_{11} ; \beta_{1}-\beta_{2}$ (nilai koefisien), $\alpha_{0} ; \beta_{0}$ (konstanta), $\varepsilon_{t-1}^{2}$ (nilai error periode sebelumnya - ARCH), $h_{t-1}^{2}$ (nilai varians periode sebelumnya GARCH).

Ukuran yang menentukan apakah hasil estimasi dari model volatilitas GARCH dianggap baik adalah nilai penjumlahan dari ARCH dan GARCH. Hasil penjumlahan yang kurang dari satu menunjukkan model yang sudah baik. Hal tersebut harus dipenuhi agar menunjukkan adanya proses kembalinya varians rata-rata. Penjumlahan yang semakin dekat dengan satu, maka proses tersebut berlangsung semakin lambat. Jika penjumlahan menghasilkan angka yang lebih dari satu, model dianggap tidak baik karena proses kembalinya varians ratarata tidak terjadi atau terus meningkat seiring dengan waktu (eksplosif). Lalu, nilai penjumlahan yang sama dengan satu mengindikasikan bahwa varians tidak beru-bah antar waktu di mana hal tersebut tidak mungkin terjadi pada data keuangan. Selain yang sudah dijabarkan sebelumnya, syarat yang harus dipenuhi sebagai ukuran baik tidaknya model adalah nilai koefisien $\beta_{0}>$ $0 ; \beta_{1} \geq 0 ; \beta_{2} \geq 0$ (Bollerslev, 1986; Engle, 2001)

\section{Metode Pengujian Statistik} Uji Stasioneritas

Menentukan apakah sebuah data sudah stasioner atau belum merupakan 
salah satu hal penting sebelum melakukan estimasi dengan menggunakan data runut waktu (time series). Stasioner merupakan suatu kondisi data yang di mana data tersebut memiliki nilai rata-rata dan varians yang tidak berubah-ubah seiring dengan waktu. Dengan nilai rata-rata dan varians yang tidak berubah seiring dengan waktu, hasil estimasi yang dihasilkan akan baik dan bukan regresi palsu (spurious regression) karena data yang tidak stasioner menunjukkan bahwa data tersebut dipengaruhi oleh kebiasaan data itu sendiri. Pengujian stasioneritas yang paling banyak digunakan adalah pengujian akar unit yang salah satunya adalah Dickey-Fuller Test (Chris, 2014).

\section{Uji Heteroskedastisitas}

Salah satu asumsi yang harus dipenuhi dalam pengolahan data merupakan asumsi homoskedastisitas, yang artinya bahwa data sudah memiliki varians dari error yang konstan. Asumsi homoskedastis yang tidak terpenuhi dapat disebut juga dengan adanya masalah heteroskedastisitas, yang di mana varians dari error berubah-ubah seiring dengan waktu. Dengan memodelkan data dengan masalah heteroskedastisitas dengan model berbasis Ordinary Least Square akan membuat hasil estimasi menjadi bias dan tidak memenuhi kriteria best linear unbiased estimators (BLUE) sehingga permodelan akan lebih baik menggunakan model volatilitas ARCH-GARCH karena model tersebut dapat menangkap adanya masalah heteroskedastisitas (Chris, 2014). Salah satu pengujian yang dapat melihat apakah varia-bel bersifat heteroskedastis adalah dengan melakukan pengujian ARCH Effect.

\section{Uji Autokorelasi}

Autokorelasi merupakan salah satu masalah yang melanggar asumsi tidak ada korelasi antar error. Masalah autokorelasi yang tidak diperbaiki akan memunculkan dampak koefisien yang diestimasi tidak efisien sehingga estimasi standard error dapat salah. Karena itu, hasil estimasi tidak akan menggambarkan yang sebenarnya dan meningkatkan kemungkinan untuk kesalahan di mana adanya kecenderungan untuk menolak hipotesis pada saat seharusnya hipotesis tersebut benar. Nilai dari $R$-squared juga cenderung tinggi jika masalah autokorelasi tidak diperbaiki karena adanya autokorelasi pada residual akan mengarah pada perkiraan yang terlalu rendah dari nilai error variance yang sebenarnya (Chris, 2014). Penelitian ini menggunakan grafik korelogram untuk melihat adanya masalah autokorelasi pada variabel tertentu.

Data yang digunakan untuk mengestimasi day-of-the-week effect sudah dilakukan metode pengujian statistik dengan hasil data sudah stasioner, terdapat ARCH effect / heteroskedastisitas, dan tidak terdapat autokorelasi. Tabel menunjukkan hasil estimasi dari tingkat pengembalian harian LQ45 dan IHSG. Sebelum dilakukan estimasi dengan menggunakan model volatilitas GARCH, maka pengujian dilaku-kan untuk melihat apakah data yang diguna-kan sudah sesuai. Hasil yang dida-pat menunjukkan bahwa data yang diguna-kan sudah stasioner, bersifat heteroske-dastis, dan tidak memiliki autokorelasi.

Hasil estimasi pada tabel 5 menunjukkan bahwa secara signifikan adanya seasonal effect atau anomali pasar yang konsisten di antara kedua indeks, yaitu bahwa rata-rata tingkat pengembalian terendah terjadi hari Senin dan rata-rata tingkat pengembalian tertinggi pada hari Rabu. Rata-rata tingkat pengembalian pada hari Jumat menunjukkan angka yang tinggi pula secara signifikan walaupun tidak setinggi hari Rabu. Lalu, estimasi yang dihasilkan dapat dikatakan sudah baik karena nilai penjumlahan dari koefisien $\mathrm{ARCH}$ dan GARCH tidak lebih dari satu untuk kedua indeks. 
Tabel 5

Hasil Estimasi Return Harian

\begin{tabular}{|c|c|c|c|c|c|c|}
\hline & \multicolumn{3}{|c|}{ LQ45 } & \multicolumn{3}{|c|}{ IHSG } \\
\hline Variabel & Return & ARCHM & ARCH & Return & ARCHM & ARCH \\
\hline L1.Return & $\begin{array}{c}0.0917^{* * *} \\
(0.0153)\end{array}$ & & & $\begin{array}{c}0.0996^{* * *} \\
(0.0154)\end{array}$ & & \\
\hline Selasa & $\begin{array}{l}0.194^{* * *} \\
(0.0552)\end{array}$ & & & $\begin{array}{l}0.183^{* * *} \\
(0.0453)\end{array}$ & & \\
\hline Rabu & $\begin{array}{l}0.284^{* * *} \\
(0.0526)\end{array}$ & & & $\begin{array}{l}0.271^{* * *} \\
(0.0428)\end{array}$ & & \\
\hline Kamis & $\begin{array}{l}0.116^{* *} \\
(0.0522)\end{array}$ & & & $\begin{array}{l}0.140^{* * *} \\
(0.0430)\end{array}$ & & \\
\hline Jumat & $\begin{array}{l}0.250^{* * *} \\
(0.0525)\end{array}$ & & & $\begin{array}{l}0.245^{* * *} \\
(0.0429)\end{array}$ & & \\
\hline Sigma2 & & $\begin{array}{l}0.0200^{*} \\
(0.0112)\end{array}$ & & & $\begin{array}{c}0.0207 \\
(0.0136)\end{array}$ & \\
\hline L1.ARCH & & & $\begin{array}{c}0.137^{* * *} \\
(0.00714)\end{array}$ & & & $\begin{array}{c}0.132^{* * *} \\
(0.00648)\end{array}$ \\
\hline L1.GARCH & & & $\begin{array}{c}0.850 * * * \\
(0.00726)\end{array}$ & & & $\begin{array}{c}0.860 * * * \\
(0.00639)\end{array}$ \\
\hline Konstanta & $\begin{array}{c}-0.128^{* * *} \\
(0.0428)\end{array}$ & & $\begin{array}{l}0.0625^{* * *} \\
(0.00687)\end{array}$ & $\begin{array}{c}-0.119 * * * \\
(0.0353)\end{array}$ & & $\begin{array}{l}0.0360^{* * *} \\
(0.00407)\end{array}$ \\
\hline Observasi & 5,113 & 5,113 & 5,113 & 5,113 & 5,113 & 5,113 \\
\hline
\end{tabular}

Hasil yang konsisten untuk kedua indeks tersebut dapat diduga akibat dari pergerakan IHSG yang sebagian besar didorong oleh Indeks LQ45. Hal itu terjadi karena emiten dari Indeks LQ45 merupakan 45 perusahaan dengan likuiditas tertinggi dan memegang kapitalisasi yang besar di pasar saham.

Tingkat pengembalian hari Senin yang paling rendah dibandingkan dengan hari lainnya dalam seminggu menunjukkan adanya jumlah investor yang menjual saham lebih banyak dibandingkan investor yang membeli saham. Hal tersebut diindikasikan terjadi karena akumulasi penjualan pada saat pasar saham tidak beroperasi di hari Sabtu dan Minggu. Tekanan jual pada hari Senin diduga dapat terjadi akibat dari munculnya berita buruk yang memengaruhi pasar saham pada akhir pekan dan kebiasaan investor yang menggunakan akhir pekan untuk mengevaluasi saham yang dimilikinya

Hasil lain dari penelitian ini adalah tingkat pengembalian hari Rabu yang paling tinggi dibandingkan hari lainnya dalam seminggu. Tingkat pengembalian tersebut menunjukkan bahwa adanya pem-belian saham yang lebih banyak diban-dingkan hari lainnya sehingga membukti-kan bahwa terjadi pembelian tertinggi dalam pasar saham. Hal tersebut diduga terjadi karena investor memiliki informasi yang cukup dari dua hari sebelumnya (Senin dan Selasa) serta memungkinkan un-tuk memprediksi pergerakan harga saham pada dua hari kemudian dalam seminggu

Hari Jumat merupakan hari dengan tingkat pengembalian kedua tertinggi dalam seminggu setelah hari Rabu. Hal ini diduga karena hari Jumat merupakan hari terakhir sebelum akhir pekan. Selain itu, adanya tekanan jual untuk menghindari 
adanya pembebanan bunga pada hari di akhir minggu dari penggunaan fasilitas marjin yang diberikan oleh perusahaan sekuritas.

Hal lain yang didapat dari penelitian ini adalah adanya hubungan antara risiko dan tingkat pengembalian yang bersifat positif secara signifikan pada tingkat signifikansi $10 \%$ untuk LQ45 sehingga menunjukkan adanya kompensasi tingkat pengembalian atas risiko pada perusahaan dengan likuiditas tertinggi di Bursa Efek Indonesia. Di lain sisi, pada IHSG, risiko tidak secara signifikan berpengaruh terhadap tingkat pengembalian pasar saham
Indonesia. Hasil tersebut ditunjukkan dengan koefisien risiko pada model tidak signifikan terhadap tingkat pengembalian IHSG sehingga semakin tinggi risiko yang diambil belum tentu akan menghasilkan tingkat pengembalian yang lebih tinggi pula walaupun hubungan dari kedua hal tersebut adalah positif. Hubungan risiko dengan tingkat pengembalian IHSG yang tidak signifikan diduga karena IHSG meru-pakan kumpulan dari seluruh emiten yang sahamnya diperdagangkan di Bursa Efek Indonesia. Selain itu, emiten tersebut memiliki kapitalisasi, kinerja, dan frekuensi perdagangan yang sangat beragam.

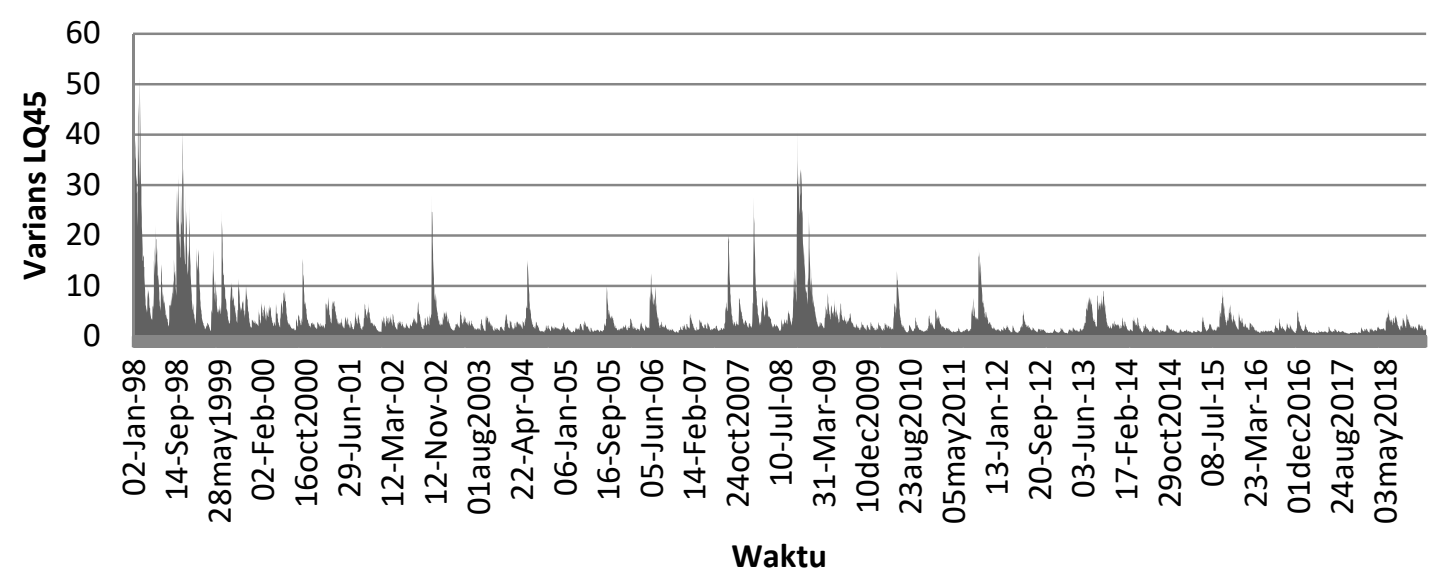

Gambar 3

Varians Return Harian LQ45 Tahun 1998-2018

Sumber: pengolahan peneliti $(2020$

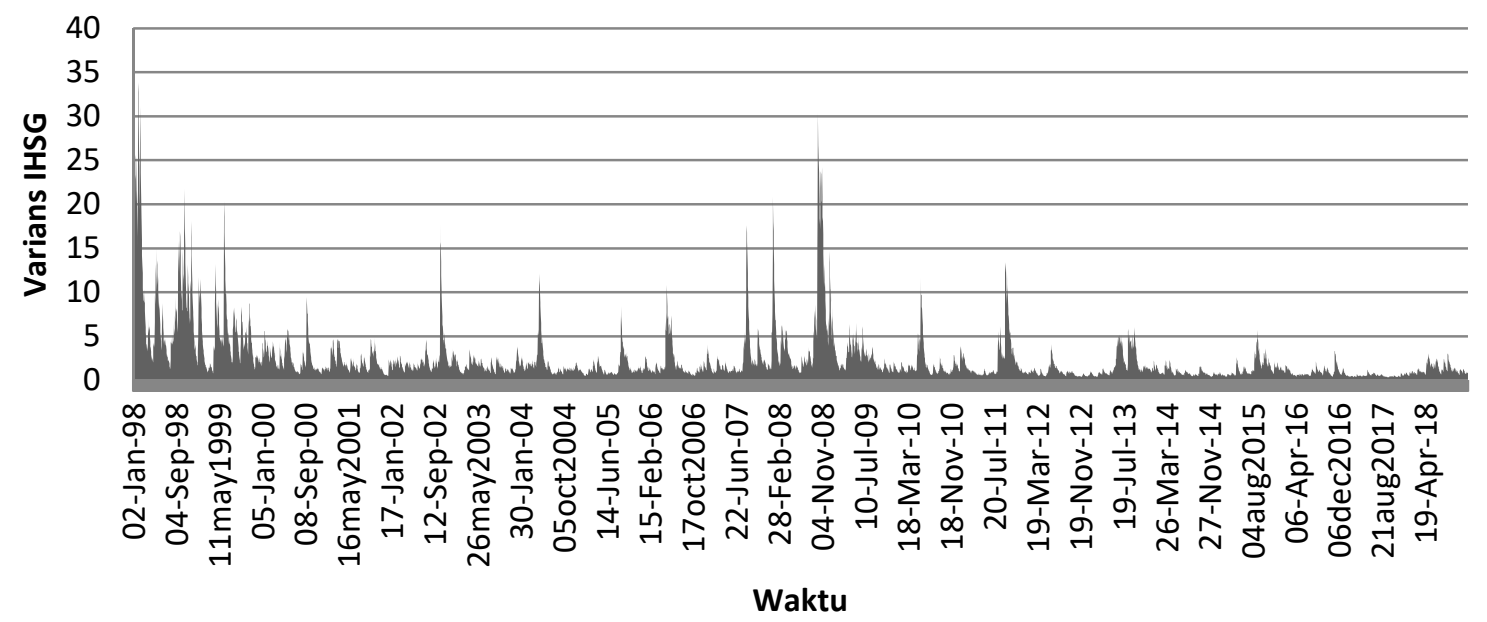

Gambar 4

Varians Return Harian IHSG Tahun 1998-2018

Sumber: pengolahan peneliti (2020) 
Gambar 3 dan 4 menunjukkan varians antar waktu untuk tingkat pengembalian kedua indeks seluruh periode. Grafik varians menunjukkan konsistensi yang sama untuk kedua indeks di mana volatilitas yang tinggi dapat terlihat pada beberapa waktu, yaitu pada tahun 1998 dan tahun 2008. Hal tersebut dapat diakibatkan karena pengaruh dari beberapa krisis yang terjadi seperti Krisis Moneter 1998 dan Krisis Keuangan Global 2008 yang memunculkan ketidakpastian besar pada saat kedua krisis tersebut terjadi.
Gambar 5 dan 6 menunjukkan rata-rata varians tingkat pengembalian harian untuk kedua grafik tersebut menunjukkan hasil yang searah di mana rata-rata varians tertinggi jatuh pada hari Selasa, sedangkan rata-rata varians terendah jatuh pada hari Kamis. Hasil tersebut menunjukkan bahwa adanya kompensasi antara risiko dengan tingkat pengembalian pada hari Rabu dan Jumat karena risiko yang tinggi diikuti pula dengan tingkat pengembalian yang tinggi pula walaupun hal tersebut tidak berlaku pada hari Selasa.

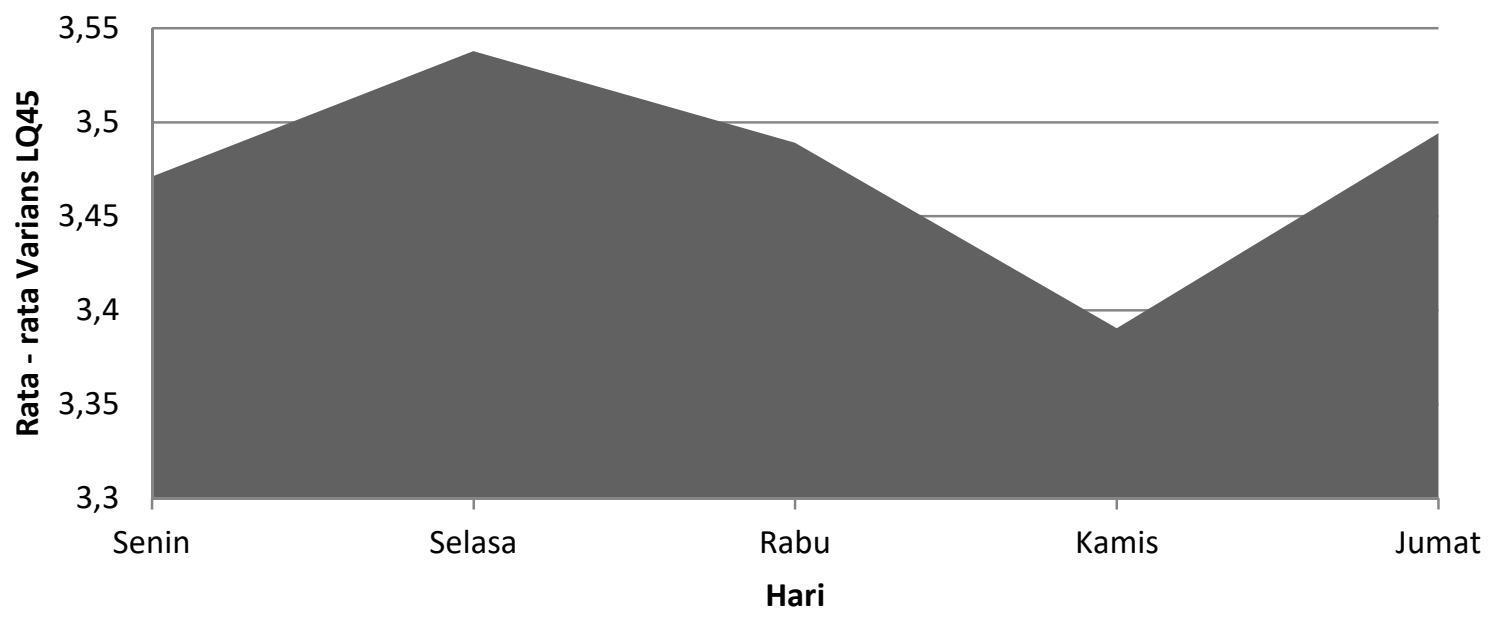

Gambar 5

Rata-Rata Varians Return Harian LQ45

Sumber: pengolahan peneliti (2020)

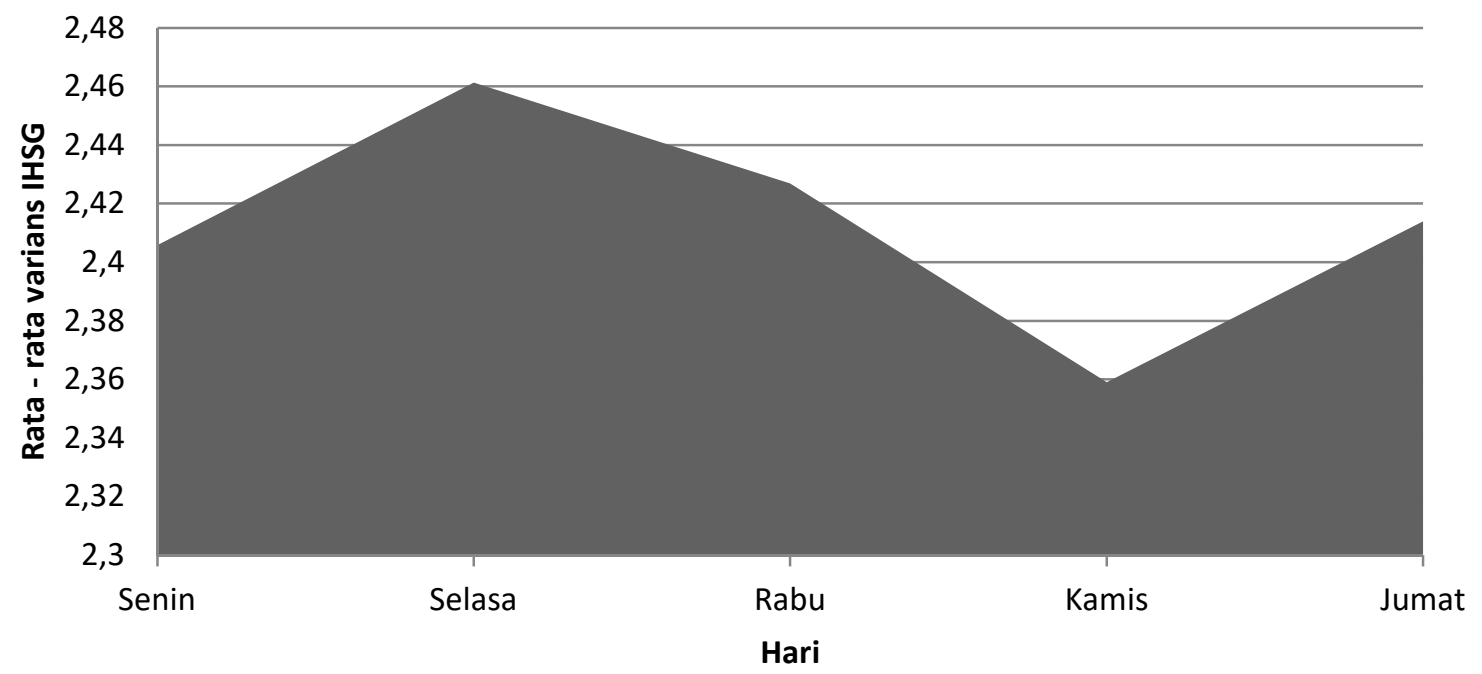

Gambar 6

Rata-Rata Varians Return Harian IHSG

Sumber: pengolahan peneliti (2020) 
Tabel 6

Hasil Estimasi Tingkat Pengembalian Bulanan

\begin{tabular}{|c|c|c|c|c|c|c|}
\hline & \multicolumn{3}{|c|}{ LQ45 } & \multicolumn{3}{|c|}{ IHSG } \\
\hline Variabel & $\begin{array}{c}\text { (1) } \\
\text { Return }\end{array}$ & $\begin{array}{c}(2) \\
\text { ARCHM }\end{array}$ & $\begin{array}{c}\text { (3) } \\
\text { ARCH }\end{array}$ & $\begin{array}{c}(4) \\
\text { Return }\end{array}$ & $\begin{array}{c}\text { (5) } \\
\text { ARCHM }\end{array}$ & $\begin{array}{c}\text { (6) } \\
\text { ARCH }\end{array}$ \\
\hline L.Return & $\begin{array}{c}0.144^{*} \\
(0.0859)\end{array}$ & & & $\begin{array}{c}0.192^{* *} \\
(0.0797)\end{array}$ & & \\
\hline Februari & $\begin{array}{l}1.096 \\
(2.311)\end{array}$ & & & $\begin{array}{c}0.975 \\
(2.019)\end{array}$ & & \\
\hline Maret & $\begin{array}{l}-0.208 \\
(1.861)\end{array}$ & & & $\begin{array}{l}-0.114 \\
(1.711)\end{array}$ & & \\
\hline April & $\begin{array}{l}-0.105 \\
(1.949)\end{array}$ & & & $\begin{array}{l}-0.305 \\
(1.748)\end{array}$ & & \\
\hline Mei & $\begin{array}{l}-1.821 \\
(1.937)\end{array}$ & & & $\begin{array}{l}-1.403 \\
(1.788)\end{array}$ & & \\
\hline Juni & $\begin{array}{l}-0.171 \\
(2.248)\end{array}$ & & & $\begin{array}{l}-0.372 \\
(1.873)\end{array}$ & & \\
\hline Juli & $\begin{array}{l}1.368 \\
(2.262)\end{array}$ & & & $\begin{array}{l}1.079 \\
(2.045)\end{array}$ & & \\
\hline Agustus & $\begin{array}{l}-3.532^{*} \\
(1.932)\end{array}$ & & & $\begin{array}{l}-3.224^{*} \\
(1.716)\end{array}$ & & \\
\hline September & $\begin{array}{c}0.444 \\
(1.971)\end{array}$ & & & $\begin{array}{c}0.307 \\
(1.803)\end{array}$ & & \\
\hline Oktober & $\begin{array}{c}0.335 \\
(2.206)\end{array}$ & & & $\begin{array}{l}0.0805 \\
(2.078)\end{array}$ & & \\
\hline November & $\begin{array}{l}-1.173 \\
(1.857)\end{array}$ & & & $\begin{array}{l}-1.056 \\
(1.795)\end{array}$ & & \\
\hline Desember & $\begin{array}{l}3.093 \\
(2.361)\end{array}$ & & & $\begin{array}{c}2.869 \\
(2.210)\end{array}$ & & \\
\hline Sigma2 & & $\begin{array}{c}0.0107 \\
(0.0122)\end{array}$ & & & $\begin{array}{c}0.0132 \\
(0.0140)\end{array}$ & \\
\hline L.ARCH & & & $\begin{array}{l}0.169^{* * *} \\
(0.0392)\end{array}$ & & & $\begin{array}{l}0.151^{* * *} \\
(0.0378)\end{array}$ \\
\hline L.GARCH & & & $\begin{array}{l}0.810^{* * *} \\
(0.0435)\end{array}$ & & & $\begin{array}{l}0.837^{* * *} \\
(0.0430)\end{array}$ \\
\hline Konstanta & $\begin{array}{c}0.477 \\
(1.671)\end{array}$ & & $\begin{array}{c}1.497 \\
(0.952)\end{array}$ & $\begin{array}{c}0.486 \\
(1.554)\end{array}$ & & $\begin{array}{c}0.677 \\
(0.566)\end{array}$ \\
\hline Observasi & 250 & 250 & 250 & 250 & 250 & 250 \\
\hline
\end{tabular}

\section{January effect}

Data yang digunakan untuk mengestimasi January effect sudah dilakukan metode pengujian statistik dengan hasil data sudah stasioner, terdapat $A R C H$ effect/heteroskedastisitas, dan tidak terdapat autokorelasi. Tabel 6 menunjukkan hasil estimasi model GARCH $(1,1)$ untuk kedua indeks. Hasil yang didapat konsisten untuk kedua indeks di mana tingkat pengembalian terendah terjadi pada bulan Agustus sedangkan tingkat pengembalian tertinggi terjadi pada bulan Desember. Bagaimana risiko mempengaruhi tingkat pengembalian 
pada hasil ini menunjukkan bahwa risiko berpengaruh positif secara tidak signifikan terhadap tingkat pengembalian untuk kedua indeks. Hasil dari estimasi ini sudah dianggap baik karena nilai penjumlahan ARCH GARCH yang tidak lebih dari satu serta data yang digunakan sudah menunjukkan tidak ada-nya stasioneritas, bersifat heteroskedastis, dan tidak memiliki autokorelasi saat dilaku-kan pengujian sebelum estimasi.

Penelitian ini menunjukkan tidak adanya January effect pada pasar saham Indonesia, tetapi anomali di mana tingkat pengembalian saham lebih tinggi dibandingkan bulan lainnya terjadi pada bulan Desember walaupun tidak signifikan. Hal ini disebabkan karena banyaknya investor yang menjual saham untuk menghindari pajak dari capital gains tidak berlaku di Indonesia. Pada bulan Desember, tingkat pengembalian yang paling tinggi dibandingkan bulan lain diduga terjadi akibat dari adanya akselerasi perekonomian negara pada akhir tahun yang ditunjukkan dengan banyaknya jumlah pendanaan yang dikeluarkan oleh pemerintah. Perusahaanperusahaan juga berupaya keras untuk meningkatkan performa mereka menjelang akhir tahun. Hal-hal tersebut didorong dengan terbitnya laporan keuangan akhir tahun pada bulan Desember. Selain itu, pendapatan dan penjualan pada bulan Desember seringkali meningkat akibat dari adanya fenomena yang disebut sebagai Santa Claus Rally sehingga saham cenderung memiliki performa yang lebih baik dibandingkan bulan lain karena investor cenderung optimis menyambut tahun baru. Pada bulan Desember pula, uang yang beredar di masyarakat lebih banyak dibandingkan dengan bulan lainnya akibat dari banyaknya tambahan penerimaan akhir tahun. Alasan lainnya dapat diakibatkan oleh fenomena window dressing, yaitu di mana manajer investasi memperbaiki performa portofolio mereka pada akhir kuartal sehingga mereka melakukan penjualan saham dengan performa kurang baik dan membeli saham dengan performa yang lebih baik.

Hasil lainnya dari penelitian ini adalah tingkat pengembalian bulan Agustus yang secara signifikan paling rendah disbandingkan bulan lainnya. Tingkat pengembalian terendah yang jatuh pada bulan Agustus diduga diakibatkan oleh beberapa faktor. Yang pertama, tingkat pengembalian diduga dipengaruhi oleh penerbitan laporan keuangan kuartal 2 yang terbit pada bulan Juli. Laporan keuangan tersebut seringkali menunjukkan tingkat inflasi negara tinggi yang disumbang besar oleh komponen pendidikan.

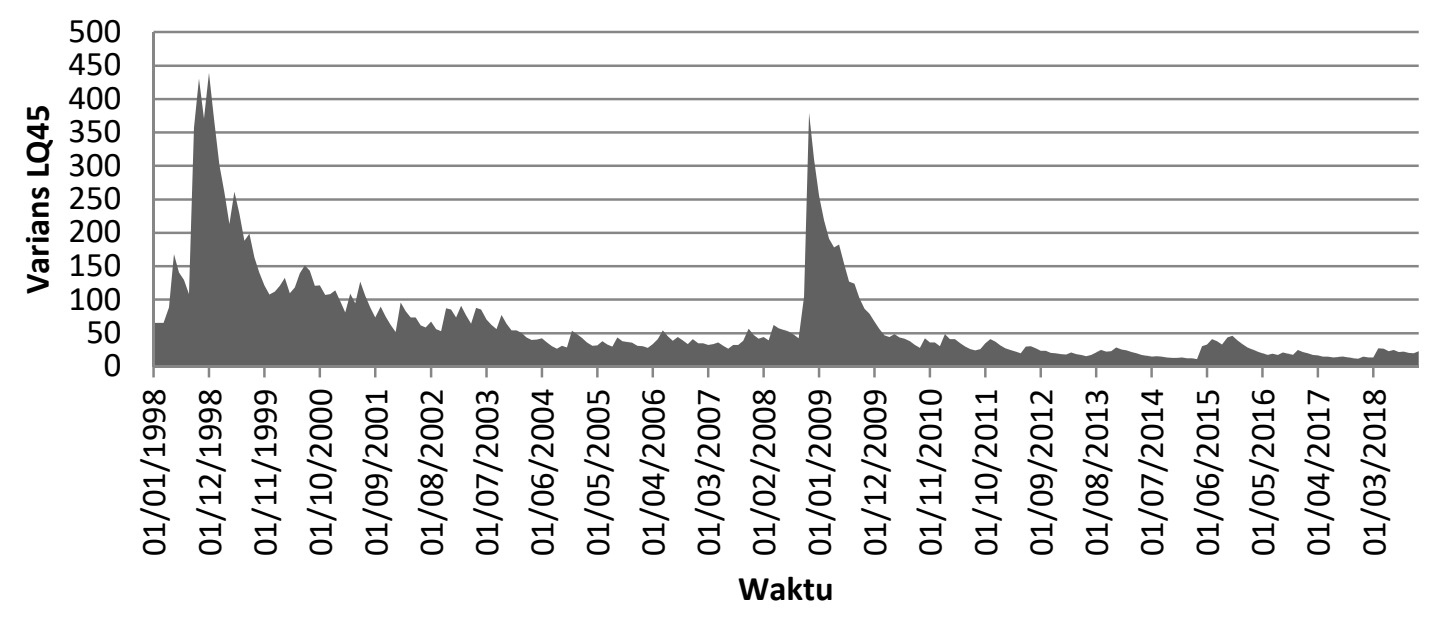

Gambar 7

Varians Return Bulanan IHSG Tahun 1998 - 2018

Sumber: pengolahan peneliti (2020) 


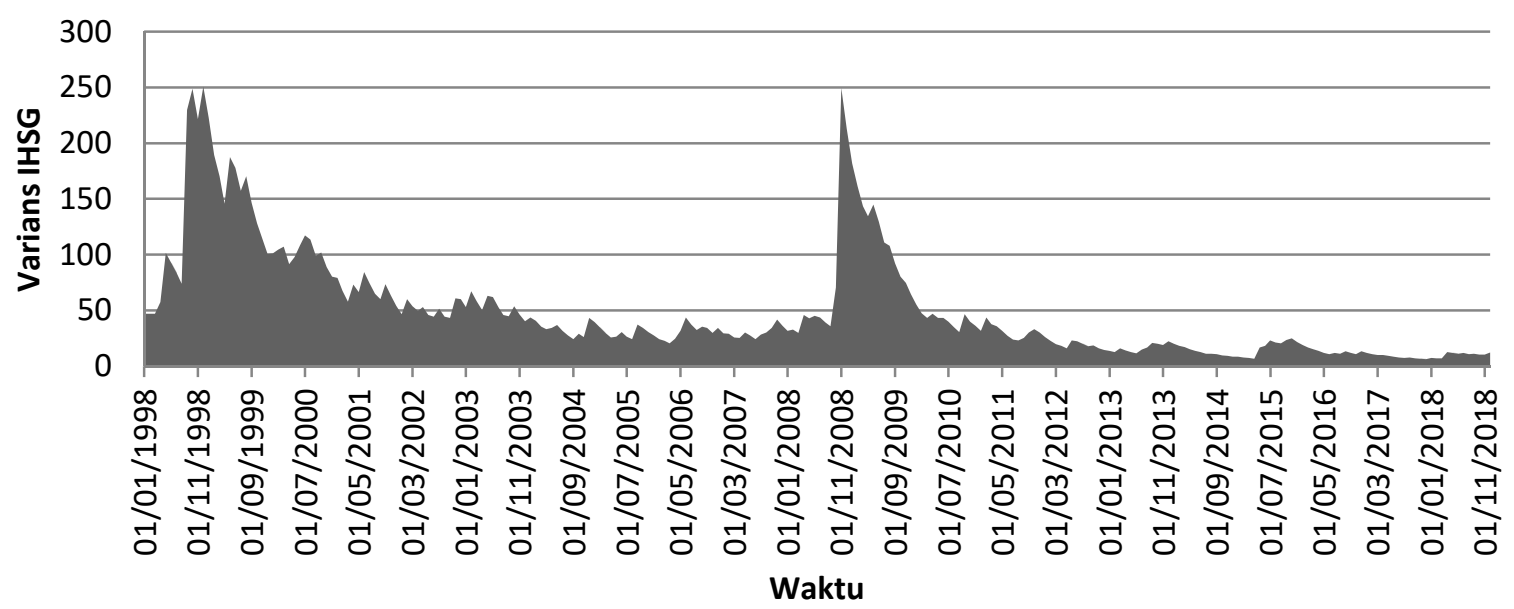

Gambar 8

Varians Return Bulanan LQ45 Tahun 1998 - 2018

Sumber: pengolahan peneliti (2020)

Hal tersebut membuktikan bahwa adanya pembayaran-pembayaran biaya pendidikan pada tengah tahun. Dugaan lainnya adalah akibat dari hadirnya libur tengah tahun pada bulan Agustus yang menyebabkan tingkat permintaan terhadap uang tinggi. Sehingga, investor menjual sahamnya untuk digunakan pada libur tengah tahun. Peristiwa tersebut mendukung dugaan bahwa banyaknya saham yang dijual akibat dari adanya kebutuhan lain yang lebih diutamakan.
Gambar 7 dan 8 menujukkan rata-rata varians antar waktu untuk tingkat pengembalian bulanan kedua indeks. Grafik tersebut menunjukkan pola yang sama untuk kedua indeks, di mana varians yang tinggi muncul pada tahun 1998-2000 dan 20092010. Hal tersebut menunjukkan bahwa harga saham bulanan pada tahun-tahun tersebut memiliki risiko yang tinggi akibat dari perubahan pergerakannya yang tinggi. Alasan dari varians yang tinggi pada waktu-waktu tersebut diduga akibat dari dampak krisis-krisis yang terjadi pada tahun tersebut.

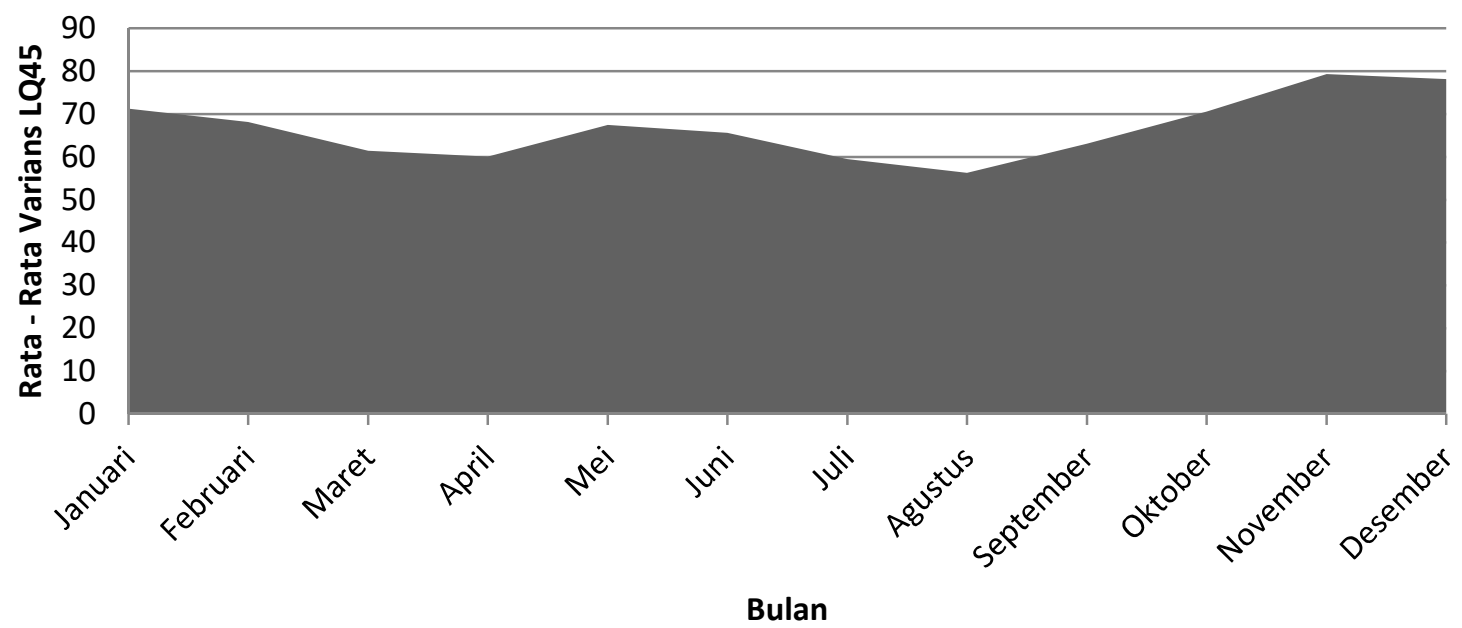

Gambar 9

Rata - Rata Varians Return Bulanan LQ45

Sumber: pengolahan peneliti (2020) 


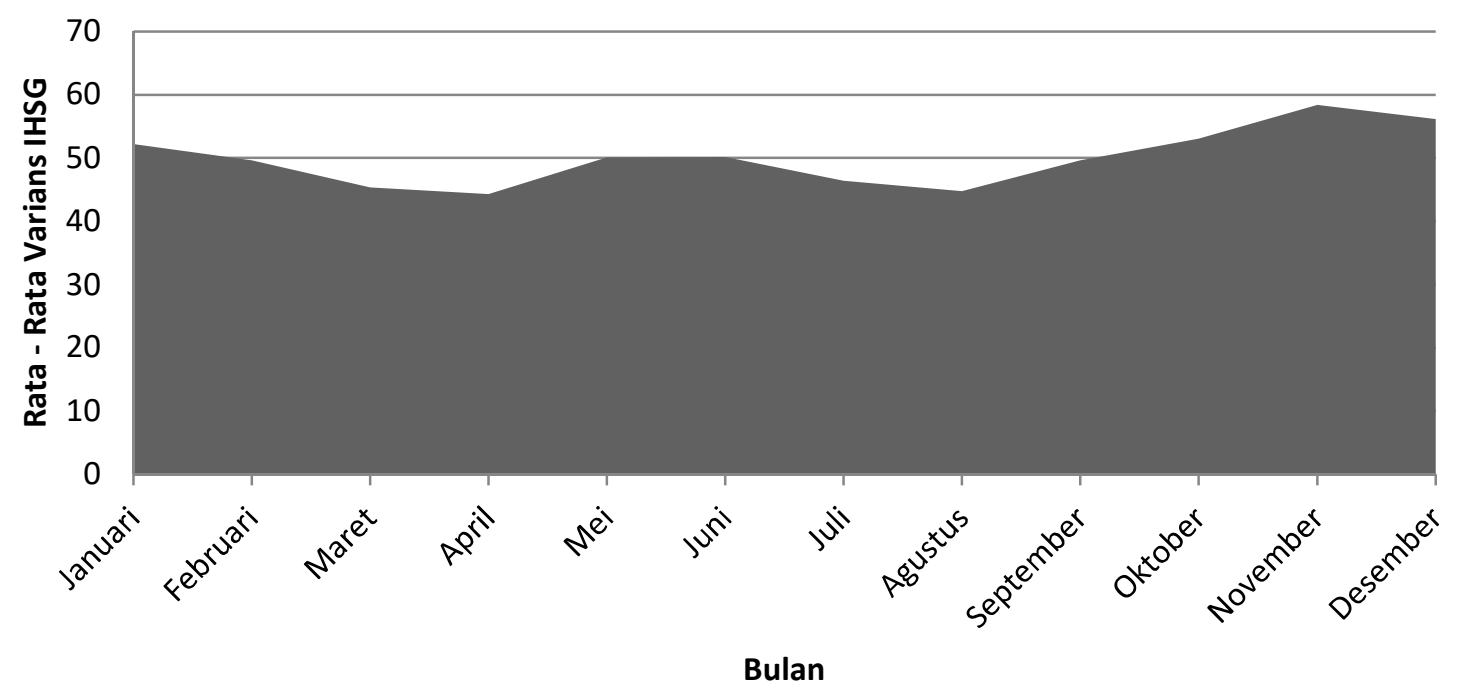

\section{Gambar 10 \\ Rata - Rata Varians Return Bulanan IHSG \\ Sumber: pengolahan peneliti (2020)}

Gambar 9 dan 10 menunjukkan perbedaan varians setiap bulannya untuk periode yang diteliti. Kedua indeks tersebut menunjukkan pergerakan yang searah, di mana varians tertinggi jatuh pada bulan November dan varians terendah jatuh pada bulan Agustus. Grafik tersebut membuktikan bahwa risiko yang lebih tinggi dikompensasi dengan tingkat pengembalian yang lebih tinggi pula karena tingkat pengembalian pada bulan Desember paling tinggi dengan varians yang tinggi pula dan tingkat pengembalian pada bulan Agustus paling rendah dengan varians yang rendah pula.

\section{SIMPULAN DAN SARAN Simpulan}

Calendar anomalies merupakan salah satu fenomena yang menunjukkan adanya seasonal effect pada tingkat pengembalian dimana adanya sifat tingkat pengembalian tertentu pada suatu waktu tertentu yang berulang. Penelitian ini bertujuan untuk melihat apakah calendar anomalies berlaku pada pasar saham di Indonesia.
Hasil yang didapat konsisten untuk Indeks LQ45 dan IHSG, bahwa adanya dayof-the-week effect atau anomali pasar di pasar saham Indonesia yang dibuktikan dengan adanya tingkat pengembalian terendah pada hari Senin dan tingkat pengembalian yang tertinggi pada hari Rabu. Lalu, untuk anomali bulanannya tidak dibuktikan adanya January effect di pasar saham Indonesia, tetapi adanya anomali pada bulan lain yaitu bulan Agustus yang memiliki tingkat pengembalian terendah secara signifikan dan bulan Desember yang memiliki tingkat pengembalian tertinggi secara tidak signifikan.

Pada Indeks LQ45 juga ditemukan bahwa risiko berpengaruh positif secara signifikan untuk data harian terhadap tingkat pengembalian tetapi tidak untuk data bulanannya walaupun keduanya bernilai positif. Hal itu menunjukkan adanya kompensasi tingkat pengembalian atas risiko yang diambil untuk data harian. Berbeda dengan hasil tersebut, pada IHSG, adanya kompensasi tingkat pengembalian atas risiko yang diambil positif secara tidak 
signifikan pada data harian maupun data bulanan.

Dengan hasil penelitian ini, dapat disimpulkan bahwa investor akan mendapatkan probabilitas lebih baik untuk tingkat pengembalian yang lebih tinggi jika melakukan pembelian saham pada hari Senin dan pada bulan Agustus yang di mana tingkat pengembalian pada waktu tersebut paling rendah dibandingkan waktu lainnya dan melakukan penjualan saham pada hari Rabu dan pada bulan Desember yang di mana tingkat pengembalian pada waktu tersebut paling tinggi dibandingkan waktu lainnya.

\section{Saran}

Pemanfaatan data berfrekuensi tinggi (harian dan/atau mingguan) dapat dipertimbangkan untuk penelitian selanjutnya. Informasi atas perilaku data berfrekuensi tinggi akan dapat dimanfaatkan oleh para investor di pasar modal, utamanya mereka yang berorientasi jangka pendek.

\section{DAFTAR PUSTAKA}

Agnani, B. dan H. Aray. 2011. The January Effect Across Volatility Regimes. Quantitative Finance 11(6): 947-953.

Ariss, R. T., R. Rezvanian, dan S. M. Mehdian. 2011. Calendar Anomalies in the Gulf Cooperation Council Stock Markets. Emerging Markets Review 12(3): 293-307.

Berument, M. H. dan N. Dogan. 2012. Stock Market Return and Volatility: Day-ofthe-Week Effect. Journal of Economics and Finance 36(2): 282-302.

Bollerslev, T. 1986. Generalized Autoregressive Conditional Heteroskedasticity. Journal of Econometrics 31(3): 307-327.

Borges, M. R. 2010. Efficient Market Hypothesis in European Stock Markets. The European Journal of Finance 16(7): 711726.

Bursa Efek Indonesia. 2019. Saham. https:// www.idx.co.id/produk/saham/.

Chris, B. 2014. Introductory Econometrics for
Finance, 3rd Edition. Cambridge University Press. United Kingdom.

Engle, R. 2001. GARCH 101: The Use of ARCH/GARCH Models in Applied Econometrics. Journal of Economic Perspectives 15(4): 157-168.

Fama, E. F. 1991. Efficient Capital Markets: II. The Journal of Finance 46(5): 15751617.

Fields, M. J. 1931. Stock Prices: a Problem in Verification. The Journal of Business of the University of Chicago 4(4): 415-418.

Fitriyani, I. 2013. Analisis January Effect pada Kelompok Saham Indeks LQ-45 di Bursa Efek Indonesia Tahun 20092011. E-Jurnal Akuntansi: 421-438.

Gitman, L. J. dan C. J. Zutter. 2015. Principles of Managerial Finance, Global Edition. Pearson Education Limited.

Guidi, F., R. Gupta, dan S. Maheshwari. 2011. Weak-form Market Efficiency and Calendar Anomalies for Eastern Europe Equity Markets. Journal of Emerging Market Finance 10(3): 337389.

Investing. 2020a. Jakarta Stock Exchange Composite (JKSE). https://id.investing. com/indices/idx-composite.

Investing. 2020b. Jakarta Stock Exchange LQ45 (JKLQ45). https://id.investing. com/indices/jakarta-lq45.

Lo, A. W. 2016. What is an Index? The Journal of Portfolio Management 42(2): 21-36.

Malkiel, B. G. dan E. F. Fama. 1970. Efficient Capital Markets: A Review of Theory and Empirical Work. The Journal of Finance 25(2): 383-417.

Mishkin, F. 2016. The Economics of Money, Banking, and Financial Markets. Encyclopedia of Finance (11th ed.). Pearson International. https:// doi.org /10.1007/0-387-26336-5_857.

Perez, G. 2018. Does the January Effect Still Exists? International Journal of Financial Research 9(1): 50-73.

Simbolon, I. P. 2015. January Effect of Stock Returns in Indonesia: The Unconditional Method and the Conditional 
Method. International Business Management 9(6): 1221-1225.

Undang-Undang Republik Indonesia Nomor 8 Tahun 1995 tentang Pasar Modal.

Urquhart, A. dan F. McGroarty. 2014. Calendar Effects, Market Conditions and the Adaptive Market Hypothesis: Evidence from Long-run US data. International Review of Financial Analysis 35: 154-166.
Wachtel, S. B. 1942. Certain Observations on Seasonal Movements in Stock Prices. The Journal of Business of the University of Chicago 15(2): 184-193.

Yahoo Finance. 2020. Jakarta Composite Index (JKSE). https://finance.yahoo. com/quote/\%5EJKSE/.

Zhang, J., Y. Lai, dan J. Lin. 2017. The Dayof-the-Week Effects of Stock Markets in Different Countries. Finance Research Letters 20: 47-62. 